\title{
Kepemimpinan Kepala Sekolah Dalam Mewujudkan Sekolah Adiwiyata Nasional di SD Negeri 18 Pekanbaru
}

\author{
Arif Budiman \\ Universitas Terbuka \\ E-mail: arifbudiman1403@gmail.com
}

\author{
Received: 13 August 2021; Revised: 02 October 2021; Accepted: 21 December 2021 \\ DOI: http://dx.doi.org/10.37905/aksara.8.1.87-100.2022
}

\begin{abstract}
Abstrak
Pembentukan sekolah Adiwiyata merupakan bagian dari kebijakan pendidikan lingkungan hidup untuk meningkatkan sikap dan perilaku peduli terhadap lingkungan. Kegiatan utama dalam Sekolah Adiwiyata adalah mewujudkan kelembagaan sekolah yang peduli dan berbudaya lingkungan bagi sekolah dasar. Langkah ataupun strategi yang dimainkan oleh sebuah lembaga pendidikan merupakan wilayah kerja seorang kepala sekolah selaku pimpinan di sekolah tersebut. Untuk itu, kepala sekolah bertugas melaksanakan fungsi-fungsi kepemimpinan, baik yang berhubungan dengan pencapaian tujuan pendidikan maupun penciptaan iklim sekolah yang kondusif bagi terlaksananya proses pendidikan secara efektif dan efisien. Penelitian ini menggunakan desain deskriptif expost facto dengan pendekatan kualitatif. Melalui metode ini peneliti mengkaji secara komprehensif terhadap fenomena-fenomena dan kejadian yang terjadi di lokasi penelitian sesuai fokus permasalahan yang telah ditentukan. Keteladanan kepala sekolah memberi contoh kepada seluruh masyarakat sekolah untuk peduli lingkungan. Beliau menunjukkan tindakan nyata untuk menggerakan seluruh masyarakat sekolahnya. Pemimpin mendiskusikan hal-hal yang akan dirapatkan untuk memperoleh gambaran sementara. Lalu dikembangkan kembali saat rapat bersama para guru-gurunya selaku masyarakat dalam sekolah. Dari mufakat bersama itu kepala sekolah menjalin hubungan dengan masyarakat luar sekolah untuk terlibat dalam mewujudkan program sekolah. Dan program itu dijalankan sesuai bagian-bagian dari masyarakat sekolah itu sampai kepada bagian pembelajarannya yang disusun bersama oleh para majelis guru selaku bawahan dari kepala sekolah. Pengaruh kepemimpinan kepala sekolah sangat besar dalam mewujudkan program adiwiyata. Karena kepemimpinan harus memberi tauladan yang baik untuk mendukung program yang direncanakannya. Pemimpin harus berpartisipasi aktif didalam dan diluar lingkungan sekolah dengan merangkul seluruh pihak terkait untuk ketercapaian program yang telah direncanakan.
\end{abstract}

Kata kunci: Kepemimpinan, Kepala Sekolah, Sekolah Adiwiyata.

\begin{abstract}
The establishment of the Adiwiyata school is part of the environmental education policy to improve attitudes and behavior to care for the environment. The main activity in the Adiwiyata School is to create a school institution that cares and is environmentally cultured for elementary schools. The steps or strategies played by an educational institution are the work area of a principal as a leader in the school. For this reason, the principal is tasked with carrying out leadership functions, both related to achieving educational goals and creating a conducive school climate for the implementation of the educational process effectively and efficiently. This study uses an ex post facto descriptive design with a qualitative approach. Through this method, the researcher reviews comprehensively the phenomena and events that occur at the research location according to the focus of the problem that has been determined. The principal's example sets an example for the entire school community to care about the environment. He showed concrete actions to mobilize the entire school community. The leader discusses the things that will be met to get a temporary picture. Then it was developed again during a meeting with the teachers as the community in the school. From this mutual consensus, the principal establishes a relationship with the community outside the school to be involved in realizing the school program. And the program is carried out according to the sections of the school community to the learning section which is compiled jointly by the teacher councils as subordinates to the principal. The influence of the principal's leadership is very large in realizing the adiwiyata program. Because the leadership must set a good example to support the planned program.
\end{abstract}


Leaders must participate actively inside and outside the school environment by embracing all relevant parties for the achievement of the planned program.

Keywords: Principal, Leadership, Adiwiyata School.

\section{PENDAHULUAN}

Pendidikan dapat memberikan efek sosial yang positif meningkatkan kesadaran terhadap lingkungan dan tanggung jawab sosial bagi peserta didik. Sekolah sebagai salah satu komponen utama dalam kehidupan anak selain keluarga perlu menanamkan sikap peduli lingkungan pada siswa perlu dilakukan sejak dini sehingga bisa terbentuk rasa menghargai dan memiliki serta bagaimana memelihara lingkungan dan menimbulkan kesadaran diri untuk bisa mengatasi masalah-masalah lingkungan yang terjadi

Berkaitan dengan lingkungan hidup, pada tanggal 19 Februari 2004 Kementerian Negara Lingkungan Hidup (KNLH) bersama-sama dengan Departemen Pendidikan Nasional, Departemen Agama dan Departemen Dalam Negeri telah menetapkan Kebijakan Pendidikan Lingkungan Hidup (PLH). Kebijakan PLH ini merupakan kebijakan dasar sebagai arahan bagi semua pemangku kepentingan (stake holders) dalam pelaksanaan dan pengembangan PLH di Indonesia. PLH diyakini sebagai solusi yang efektif dan efisien dalam upaya meningkatkan pengetahuan dan pemahaman masyarakat terhadap pelestarian fungsi lingkungan hidup.

Permasalahan lingkungan hidup tidak dapat dipisahkan secara teknis semata, namun yang lebih penting adalah pemecahan yang dapat mengubah mental serta kesadaraan akan pengelolaan lingkungan. Untuk mengatasi dampak kerusakan lingkungan hidup diperlukan suatu perubahan sikap dan perilaku pada masyarakat serta perbaikan moral melalui pendidikan.

Pendidikan sangat mempengaruhi perkembangan fisik, daya jiwa (akal, rasa dan kehendak), sosial dan moralitas manusia serta alat terpenting untuk menjaga diri dan memelihara nilai-nilai positif. Tentunya dengan pengaruh yang ditimbulkan pendidikan ini memberikan dampak pada bertambahnya pengetahuan dan keterampilan serta akan menolong dalam pembentukan sikap yang positif. Pendidikan memberikan peluang kepada masyarakat untuk melakukan suatu tindakan atau pengalaman yang mempengaruhi pertumbuhan atau perkembangan jiwa, watak, atau kemampuan fisik mereka melalui lembaga-lembaga pendidikan yang dengan sengaja mentransformasikan warisan budayanya, yaitu pengetahuan, nilai-nilai dan keterampilan-keterampilan dari generasi ke generasi. Semua pihak diharapkan dapat turut serta melakukan penyelamatan dan pelestarian lingkungan hidup dengan mengembangkan sikap, bentuk-bentuk perilaku, kemampuan sosial dan kemampuan individu yang mencintai lingkungan

Sebagai respon dikeluarkannya kebijakan tiga kementerian salah satu solusi sektor pendidikan adalah pembentukan Sekolah Adiwiyata. Program Adiwiyata adalah salah satu program Kementerian Negara Lingkungan Hidup dalam rangka mendorong terciptanya pengetahuan dan kesadaran warga sekolah sehingga menjadi insan yang berkarakter peduli lingkungan dalam upaya pelestarian lingkungan hidup. Kementerian Lingkungan Hidup mengeluarkan keputusan No. 5 Tahun 2013 tentang program pendidikan lingkungan hidup pada jenjang pendidikan dasar dan menengah melalui program Adiwiyata.

Pembentukan sekolah Adiwiyata merupakan bagian dari kebijakan pendidikan lingkungan hidup untuk meningkatkan sikap dan perilaku peduli terhadap lingkungan. 
Tujuannya adalah menciptakan kondisi yang baik bagi sekolah sebagai tempat pembelajaran dan penyadaran warga sekolah, sehingga dikemudian hari warga sekolah tersebut dapat turut bertanggungjawab dalam upaya-upaya penyelamatan lingkungan hidup dan pembangunan berkelanjutan. Kegiatan utama dalam Sekolah Adiwiyata adalah mewujudkan kelembagaan sekolah yang peduli dan berbudaya lingkungan bagi sekolah dasar dan menengah di Indonesia (Haris, Abas, and Wardiana 2018).

Program Adiwiyata bertujuan untuk menciptakan kondisi yang baik bagi sekolah untuk menjadi tempat pembelajaran dan penyadaran warga sekolah yang diwujudkan dalam bentuk: (1) pengembangan kebijakan sekolah peduli dan berbudaya lingkungan, (2) pengembangan kurikulum berbasis lingkungan, (3) pengembangan kegiatan lingkungan berbasis partisipatif, dan (4) pengembangan dan pengelolaan sarana pendukung sekolah berbudaya lingkungan.

Salah satu sekolah yang telah menerapkan konsep go green school sekaligus pencetus pertama atau role model Sekolah adiwiyata adalah SD Negeri 18 Pekanbaru. Sahran Ritongga selaku ketua tim Adiwiyata sekolah menjelaskan bahwa Program ini dimulai pada tahun 2004 dengan mendapat penghargaan pertama yakni penganugerahan adiwiyata nasional tingkat 1 tahun 2007. Penganugerahan ini setara dengan penganugerahan Sekolah Adiwiyata tingkat provinsi pada sekarang ini. Karena saat itu SD Negeri 18 Pekanbaru adalah satu-satunya sekolah dasar yang membawa program adiwiyata ketingkat pusat mewakili pulau sumatera dan langsung mendapat anugerah Sekolah Adiwiyata Tingkat nasional dari Bapak Presiden Susilo Bambang Yudhoyono. Setelah mendapatkan anugerah adiwiyata tingkat nasional, SD Negeri 18 Pekanbaru meningkatkan kualitas program adiwiyata dengan menjaga dan meningkatkan inovasiinovasi terkait peduli lingkungan dan pengimbasan kepada sekolah-sekolah lain dari tingkat Sekolah dasar sampai ke menengah ke atas.

Sejak diterapkannya program adiwiyata pada SD Negeri 18 Pekanbaru, secara bertahap seluruh sekolah yang ada dikota Pekanbaru terutama tingkat sekolah dasar terpacu untuk mewujudkan program adiwiyata. Karena program adiwiyata mampu melestarikan lingkungan sekolah sampai kepada proses pembelajarannya yang menjadikan masyarakat sekolah peduli dengan lingkungan.

Ada sekolah yang mendapatkan anugrah adiwiyata tingkat kota dan propinsi. Tapi kedua sekolah ini tidak mau melanjutkan pada level yang lebih tinggi dikarenakan tidak semua warga sekolah yang mau berpartisipasi aktif dalam program ini. Seperti hasil temuan awal peneliti pada saat wawancara dengan ketua adiwiata pada SD Negeri 126 dan 137 Pekanbaru.

Langkah ataupun strategi yang dimainkan oleh sebuah lembaga pendidikan merupakan wilayah kerja seorang kepala sekolah selaku pimpinan di sekolah tersebut. Kepala sekolah sebagai sosok ataupun figur yang menjadi motor penggerak kemajuan lembaga pendidikan tentu memiliki strategi agar sekolah yang dipimpinya menjadi sekolah yang bermutu. Untuk itu, kepala sekolah bertugas melaksanakan fungsi-fungsi kepemimpinan, baik yang berhubungan dengan pencapaian tujuan pendidikan maupun penciptaan iklim sekolah yang kondusif bagi terlaksananya proses pendidikan secara efektif dan efisien.

Berdasarkan fenomena yang telah dipaparkan, peneliti tertarik untuk meneliti peran kepemimpinan kepapa sekolah dalam mewujudkan sekolah adiwiyata. 
AKSARA: Jurnal Ilmu Pendidikan Nonformal

P-ISSN 2407-8018 E-ISSN 2721-7310 DOI prefix 10.37905

Volume 08, (1), January 2022

http://ejurnal.pps.ung.ac.id/index.php/Aksara

\section{METODE PENELITIAN}

Penelitian ini menggunakan desain deskriptif expost facto dengan pendekatan kualitatif. Melalui metode ini peneliti mengkaji secara komprehensif terhadap fenomenafenomena dan kejadian yang terjadi di lokasi penelitian sesuai fokus permasalahan yang telah ditentukan. Hakikatnya penelitian kualitatif berusaha mengamati orang dalam lingkungan hidupnya, beinteraksi dengan sesama, berusaha memahami bahasa dan tafsiran mereka tentang dunia sekitarnya.

Desain penelitian ini dipilih atas dasar beberapa pertimbangan antara lain pertama, penelitian ini berusaha mencari gambaran perilaku masyarakat sekolah yang melaksanakan program sekolah adiwiyata. Kedua, peneliti dapat berinteraksi secara langsung -dengan kepala sekolah, dan guru- guru terutama ketua tim adiwiyata di sekolah tersebut sehingga memperoleh keakuratan data secara alamiah. Ketiga peneliti dapat mengamati secara langsung lingkungan sekolah adiwiyata dengan pedoman program sekolah adiwiyata berdasarkan peraturan menteri lingkungan hidup, dan keempat, peneliti mengumpulkan bukti- bukti fisik terkait keberhasilan sekolah dalam program adiwiyata.

Instrumen yang digunakan dalam penelitian ini adalah pedoman wawancara berupa daftar pertanyaan yang digunakan sebagai panduan saat wawancara dengan para informan, dan pedoman observasi yang digunakan sebagai saat melakukan observasi disekolah. Wawancara dalam penelitian ini dilakukan dengan metode wawancara terstruktur dengan tujuan menemukan permasalahan secara lebih terbuka dan terarah.

Langkah-langkah yang dilakukan pada analisis data adalah (1) penyederhanaan data dengan memilih dan menyeleksi setiap data yang masuk dari hasil observasi, wawancara, dan dokumentasi. Data difokuskan pada pendapat informan yang telah ditentukan terhadap informasi yang dihasilkan dalam penarikan kesimpulan. Reduksi data diperlukan untuk memilah relevan tidaknya data dengan tujuan penelitian. (2) seluruh catatan lapangan berdasarkan pertanyaan yang telah dilakukan akan dikumpulkan menjadi data primer. Data primer yang diperoleh dari hasil wawancara dibuat transkrip wawancara terlebih dahulu untuk pengolahan data. Melalui transkrip wawancara dilakukan analisis agar dapat memahami pemikiran informan. (3) Data diuraikan untuk memberikan kutipan penting pada kata atau frasa yang mewakili tema penting (dan berulang) di setiap tanggapan. Kutipan ini bisa berupa kata, frasa pendek, atau angka; karena lebih mudah diingat, dibaca sekilas, dan diatur. Data transkrip wawancara dibaca dengan teliti dan hati-hati untuk menentukan kode yang dapat mewakili beberapa ide dan pemikiran yang sama. Setelah itu data disusun kembali dengan cara yang baru untuk membuat keputusan berdasarkan data yang diperoleh. Proses ini membuat proses analisis lebih mudah dan penafsiran lebih akurat. Untuk menjaga prinsip anonimitas dan membuat penyusunan laporan lebih efektif dan efisien, Informan diberi kode I1 sampai I7. Setiap kutipan yang ditunjukan dalam pemaparan hasil diakhiri menggunakan kode partisipan yang menyatakan pernyataan tertentu. (4) proses penggabungan terhadap sebuah hasil dari analisis dengan berbagai macam pertanyaan, kriteria, maupun pada standar tertentu guna untuk dapat menciptakan makna dari adanya data yang telah dikumpulkan. (5) mengkaitkan teori dengan hasil penelitian untuk memberikan penjelasan yang mendalam mengenai pemikiran informan (6) memvalidasi keabsahan data primer yang diperoleh. dengan membandingkan dan mengecek ulang antara hasil wawancara mendalam yang dilakukan terhadap masyarakat sekolah (Kepala sekolah, ketua adiwiyata, guru-guru, dan Staf Tata usaha). 


\section{HASIL DAN PEMBAHASAN}

Tujuan penelitian ini adalah untuk mendeskripsikan Kepemimpinan kepala sekolah dalam mencapai sekolah adiwiyata nasional di Sekolah Dasar Negeri 18 Pekanbaru dan mengidentifikasi faktor yang mendukung serta menghambat pelaksanaan program adiwiyata melalui wawancara terhadap informan yang telah ditetapkan sebelumnya. Hasil penelitian ini akan dibahas untuk mengetahui kepemimpinan kepala sekolah dalam mewujudkan program adiwiyata dengan pelaksanaannya di sekolah serta menganalisis faktor apa saja yang menjadikan kepemimpinan kepala sekolah dalam mewujudkan sekolah adiwiyata dari dimensi kompetensi kepribadian, manajerial, kewirausahaan, supervisi, dan sosial.

Program sekolah adiwiyata adalah program yang bermanfaat bagi sekolah dalam rangka menanamkan nilai-nilai cinta lingkungan. Program adiwiyata memberikan ruh kepada masyarakat sekolah untuk membangun kesadaran dalam menanamkan nilai-nilai cinta lingkungan kepada anak sejak dini. Tujuannya adalah supaya peserta didik yang tamat dari sekolah dasar mampu melakukan perubahan untuk mencintai lingkungannya sendiri sehingga peserta didik akan menjadi generasi yang cinta lingkungan dan agenagen perubahan bagi generasi dimasa yang akan datang.

Program adiwiyata tidak sekedar membuang sampah pada tempatnya, atau penghijauan sekolah dengan melaksanakan penanaman pohon dan bunga, tetapi program adiwiyata mampu mengubah kebiasaan menjadi pembiasaan untuk peduli dan cinta lingkungan dengan menanamkan nilai-nilai karakter yang cinta dan peduli lingkungan. Sehingga itulah yang menjadi karakteristik peserta didik di SD Negeri 18 Pekanbaru. Dari hal-hal yang kecil masyarakat sekolah SD Negeri 18 Pekanbaru memulai secara bertahap dalam menanamkan nilai-nilai cinta lingkungan. Penanaman nilai-nilai ini dilakukan secara continue dan terus tertanam pada diri masyarakat sekolah untuk membangun nilainilai karakter yang cinta dan peduli lingkungan. Sehingga diperoleh penganugerahan sekolah adiwiyata tingkat nasional oleh Menteri lingkungan hidup sekaligus yang piagam penghargaanya diserahkan langsung oleh bapak Presiden Susilo bambang Yudhoyono. Selain meraih penghargaan, penanaman nilai-niai cinta lingkungan merupakan karakteristik masyarakat sekolah SD Negeri 18 Pekanbaru.

Lampiran Menteri Pendidikan Nasional No. 13 Tahun 2007 tentang Standar Kepala Sekolah yang terbagi menjadi lima yaitu kompetensi kepribadian, manajerial, kewirausahaan, supervisi, dan sosial.

\section{Kepribadian}

Keteladanan kepala sekolah memberi contoh kepada seluruh masyarakat sekolah untuk peduli lingkungan. Beliau menunjukkan tindakan nyata untuk menggerakan seluruh masyarakat sekolahnya. Datang pagi dang mengenglilingi sekolah untuk meninjau sekitar lingkungan sekolah. Beliau memberi kepercayaan kepada bawahannya dalam menjalankan program adiwiyata sekolah. Perencanaan-perencanaan yang beliau buat selalu dimusyawarahkan dan dijalankan bersama hasil musyawarah itu dengan para bawahannya. Kendala-kendala yang ditemukan beliau diskusikan dengan bawahannya dan bersama mencari solusinya.

Kepala sekolah mampu menyandingkan, mengembangkan dan menjaga kepedulian lingkungan terhadap seluruh masyarakat sekolah. Pembiasaan ini kita tanamkan kepada anak sejak usia sekolah dasar. Dari sekolah kita akan 
mengembangkannya sampai ke lingkungan diluar sekolah. Dengan menyandingkan pengetahuan dan praktek cinta lingkungan maka akan berkembang nilai-nilai cinta lingkungan. Nilai-nilai cinta lingkungan yang sudah tertanam akan terjaga jika kita pihak sekolah mengembangkan nilai-nilai cinta lingkungan yang terdapat pada program adiwiyata.

Kepala sekolah mengajak seluruh masyarakat sekolahnya untuk peduli lingkungan dengan membentuk program adiwiyata yang terdiri dari beberapa bagian. Setiap bagian memiliki tim untuk bertanggung jawab dalam bagian program adiwiyata sekolah. Program kerja yang disusun itulah dilaksanakan bersama-sama sesuai SK yang diterbitkan dari tanda tangan pemimpin selaku pemberi kepercayaan kepada bawahannya. dari sinilah akan muncul keterbukaan berkomunikasi antara bawahan dengan pimpinan.

Bagian-bagian kerja itulah yang dikerjakan oleh anggota tim untuk kelangsungan program adiwiyata sekolah. Sehingga anggota tim bekerja dengan teratur bersama seluruh masyarakat sekolahnya.

Kepemimpinan merupakan kemampuan dalam diri seseorang dan mencakup sifatsifat, seperti kepribadian, kemampuan, dan kesanggupan. Kepemimpinan tidak dapat dipisahkan dari gaya, perilaku, dan kedudukan pemimpin bersangkutan dan interaksinya dengan para pengikut serta situasi.

\section{Manajerial}

Pemimpin mendiskusikan hal-hal yang akan dirapatkan untuk memperoleh gambaran sementara. Lalu dikembangkan kembali saat rapat bersama para guru-gurunya selaku masyarakat dalam sekolah. Dari mufakat bersama itu kepala sekolah menjalin hubungan dengan masyarakat luar sekolah untuk terlibat dalam mewujudkan program sekolah. Dan program itu dijalankan sesuai bagian-bagian dari masyarakat sekolah itu sampai kepada bagian pembelajarannya yang disusun bersama oleh para majelis guru selaku bawahan dari kepala sekolah.

Kiat-kiat menciptakan sekolah yang kondusif dengan memberi contoh, merangkul, dan bekerja bersama-sama untuk satu tujuan yang akan dicapai bersama demi mewujudkan program adiwiyata sekolah. Adanya keterbukaan, saling memiliki, dan saling berkomunikasi antara kepala sekolah dengan sesama masyarakat sekolahnya dalam mewujudkan program adiwiyata.

Kepala sekolah memerintahkan seluruh guru-gurunya untuk mengajak dan memerintahkan anak-anak dalam menjaga kebersihan lingkungan terutama lingkungan kelas yang telah dipimpin oleh guru kelasnya masing-masing. Selain itu guru piket juga menanungi beberapa anak yang ditugaskan untuk membersihkan sekitar pekarangan sekolah seperti taman dan kantor sekolah. Tugas itu sudah dibuat jadwalnya oleh guruguru dan dijalankan oleh guru piket supaya tidak terjadi benturan tanggung jawab dari masing-masing kelas yang bertanggung jawab. Guru piket memgang tanggung jawab untuk memerintahkan anak-anak dalam kebersihan lingkungan sekolah secara keseluruhan dan itu dijaga oleh guru piket dari anak masuk sampai pulang sekolah. Karena jika ini lalai maka anak-anak tanpa dia sadari akan membuang sampah sembarangan pada jam istirahat. Inilah yang selalu dipantu oleh guru piket dengan anakanak yang yang kelasnya telah dijadwalkan untuk piket mingguan.

Kiat-kiat menciptakan iklim dan budaya yang kondusif berarti memanajemenkan dulu pelaksana programnya. Berarti guru-gurunya disini diarahkan untuk bisa 
melaksanakan program secara benar dan baik dulu. Supaya anak-anak yang akan kita arahkan sebagai subjek pembelajaran untuk menciptakan budaya iklim yang kondusif ini bisa tercipta.

Kepemimpinan itu harus menunjukan sikap nyatanya sebelum mengajak seluruh orang-orang yang dinaunginya dengan sikap keterbukaan dan komunikasi yang baik. Setelah itu guru sebagai bawahan langsung dari kepala sekolah harus mampu menunjukkan sikap keterbukaan dan komunikasinya dengan anak-anak dalam menciptakan lingkungan yang sesuai program adiwiyata sehingga dengan itu akan terwujudnya program yang direncanakan bersama dengan efektif dan efisien.

Kepala sekolah meletakkan jabatan-jabatan guru itu sesuai dengan intelegensi dan potensi dari setiap guru itu. Setelah itu beliau evaluasi kinerja guru-guru tersebut dan setiap tahun ajaran baru beliau tukar posisi bagian guru itu berdasarkan potensi dan kelemahan dari setiap guru-gurunya. Dari sinilah bisa pengelolaan sumber daya manusia untuk meningkatkan kualitas dan mutu pendidikan di SDN 18 Pekanbaru.

Kompetensi Manajerial kepemimpinan kepala sekolah dalam mengkonsep sekolah adiwiyata yang melibatkan masyarakat sekolah Basri (2017) menjelaskan bahwa Kepala Sekolah membuat perencanaan dengan melibatkan semua pihak untuk kesiapan adiwiyata, pembentukan tim adiwiyata, membuat jadwal program pembinaan dari dinas lingkungan hidup, merancang program sekolah adiwiyata dan mensosialisasi program adiwiyata di lingkungan sekolah dan lingkungan masyarakat.

Pengelolaan sarana dan prasarana tim koordinator. Tim inilah yang akan mengkoordinir dan guru sebagai tim eksekutor harus berperan disana. Tidak lepas dari kerjasama yang kuat Karena untuk sarana program adiwiyata ini sangatlah banyak. Ketersediaan sarana dan prasarana sekolah yang mendukung program adiwiyata maka dibentuklah sebuah tim yang ditugaskan untuk mengurus sarana prasarana sekolah. Tim ini mengkoordinir guru-guru dan siswa untuk mengelola sarana dan prasarana sekolah sesuai bagian dan tanggung jawabnya. Karena guru menjadi tim eksekutor yang sangat berperan dalam menangani masalah sarana dan prasana bersama siswa-siswanya. Sehingga tim sarana dan prasarana tidak terlalu berat dalam mempertanggung jawabakan kewajibannya dan akan terciptanya pemerataan tugas dalam mewujudkan program adiwiyata sekolah.

Upaya yang dilakukan kepala sekolah untuk menjalin hubungan sekolah dan masyarakat dalam mewujudkan program adiwiyata yakni dengan mengundang wali murid bekerjasama dengan lingkungan sekitar dari dunia usaha, wali murid sekolah, dan masyarakat sekitar sekolah dalam rangka peduli lingkungan sekolah. Trisentra pendidikan itu sangat mendukung yaitu kepala sekolah, guru, dan orang tua dan ini yang pokoknya pemerintah akan mendukung program sekolah jika tiga bagian itu mendukung. di SDN 18 Pekanbaru ujung tombaknya itu 1 visi, 1 arah, dan 1 tujuan dan ini yang penting. Sehingga kita di SDN 18 Pekanbaru meraih penghargaan sekolah adiwiyata nasional sampai adiwiyata nasional. Dari penjelasan diatas kita simpulkan bahwa trisentra pendidikan yaitu sekolah, pemerintah, dan masyarakat sangat berhubungan erat untuk ketercapaiannya visi misi yang dibentuk oleh program sekolah.

Monotiring dan pelaporan pelaksanaan program dengan melakukan kunjungan lapangan dan mengevaluasi pada rapat sekolah. Lalu Program yang sudah sepakati dengan kepala sekolah dan guru-guru dibuat dalam program kerja. Dalam skala waktu yang ditentukan sesuai dengan indicator-indikator program kerja itu dimonitoring dan 
dievaluasi. Setelah itu dibuatlah pelaporan dari hasil program kerja itu. Dari pernyataan keduan informan tersebut program kerja itu disepakati dan dijalankan bersama. Lalu dimonitoring untuk dievaluasi. Setelah itu dirapatkan untuk ditindak lanjuti dari evaluasi tersebut untuk dicari solusinya bersama. Dari situlah baru dijadikan pelaporan hasil program kerja itu.

Rencana tindak lanjut dari evaluasi dan pelaporan dari program adiwiyata adalah kesdaran peduli akan lingkungan. Kalau memang program itu bagus kita laksanakan, kita tingkatkan lagi. Tapi jika ada kendala maka kita evaluasi apakah ini perlu dilaksanakan lagi atau tidak. Jadi ada catatan-catatan dan itu kunci dari evaluasi program yang kita laksanakan itu. Jadi tindak lanjut dari program itu tergantung dari pelaksanaannya. Jika program itu bagus maka akan diteruskan dan ditingkatkan. Namun jika program itu tidak efektif maka akan dicari solusinya dengan tujuan dari indicator program yang sama.

Pengelolaan pengembangan kurikulum dengan memasukan nilai-nilai cinta lingkungan kedalam kompetensi dasar dan indicator pada setiap pelajaran yang sesuai. Nilai-nilai cinta lingkungan itu ditanamkan pada proses pembelajaran. Mata pelajaran khusus yang terkait dengan program adiwiyata yaitu mata pelajaran pendidikan lingkungan hidup (PLH). Mata pelajaran ini termasuk kedalam muatan lokal dan memiliki nilai khusus sama seperti mata pelajaran yang lain. Mata pelajaran ini memiliki buku refrensi yang langsung diterbitkan dari dinas lingkungan hidup.

Program pembelajaran dibuat dengan mengintegrasikan antara lingkungan dengan pelajaran dan program adiwiyata. Didalam RPP itu dimasukan muatan pendidikan lingkungan hidup atau disingkat PLH. Ada 2 sistem yang digunakan sekolah untuk memasukan materi lingkungan hidup kedalam pembelajaran yakni terintegrasi dan terpisah. Terintegrasi yaitu dipadukan dengan mata pelajaran yang lain yang materi pelajaran itu ada kaitannya dengan lingkungan hidup sedangkan terpisah dibuat khusus dalam sebuah mata pelajaran dengan program pembelajaran yang terpisah dengan mata pelajaran yang lain dan fokus pembahasannya hanya pada pendidikan lingkungan hidup. Sehingga pendidikan lingkungan hidup di SDN 18 Pekanbaru dibentuk dengan sistem terintegrasi dan terpisah. Terintegrasi yaitu dipadukan dengan mata pelajaran lain yang materi pelajaran masih ada kaitannya dengan lingkungan hidup sedangkan terpisah dibuat khusus dalam sebuah mata pelajaran dengan program pembelajaran sampai kepada penilaiannya yang terpisah dengan mata pelajaran yang lain dan fokus pembahasannya hanya pada pendidikan lingkungan hidup sehingga ketercapaian nilai-nilai cinta lingkungan pada diri siswa akan cepat tercapai dan percepatan pencapaian program adiwiyata disekolah semakin lebih baik.

Pemanfaatan teknologi informasi Memposting ke media social setiap kegiatan lingkungan, meliput kegiatan tentang lingkungan dengan mengundang media masa seperti Koran, stasiun televisi. Hal ini berguna untuk mempromosikan sekolah dan bukti sedang melaksanakan program adiwiyata kepada khalayak agar bisa dicontoh program yang sedang dijalankan sekolah tersebut oleh sekolah lain.

Peran ketatausahaan dengan mengarsipkan dokumen-dokumen sekolah sebagai bukti penyelenggaraan program adiwiyata yang bisa dipertangungjawabkan oleh pihak terkait seperti dinas lingkungan hidup kota, provinsi, sampai kepada kementrian lingkungan hidup selaku pihak tertinggi yang mengeksekusi pertanggung jawaban sekolah dalam menjalankan program adiwiyata. 
Dalam system informasi sekolah menyampaikannya dalam rapat dengan majelis guru, menempelkan mading yang berkaitan dengan program adiwiyata, dan selalu membuat informasi tertulis kepada seluruh warga sekolah berdasarkan perintah kepala sekolah dan koordinasi dari ketua tim adiwiyata. Informasi yang disampaikan selalu kontiniutas dan terbaru sebagai upaya tindak lanjut dari keberlangsungan program adiwiyata yang sedang berlangsung disekolah.

Kompetensi Manajerial kepemimpinan kepala sekolah dalam mengkonsep sekolah adiwiyata yang melibatkan masyarakat sekolah Basri (2017) menjelaskan bahwa Kepala Sekolah membuat perencanaan dengan melibatkan semua pihak untuk kesiapan adiwiyata, pembentukan tim adiwiyata, membuat jadwal program pembinaan dari dinas lingkungan hidup, merancang program sekolah adiwiyata dan mensosialisasi program adiwiyata di lingkungan sekolah dan lingkungan masyarakat.

Menurut Assauri (2013), keberhasilan suatu organisasi ditentukan oleh kemampuan pimpinan organisasi itu menetapkan strategi yang tepat dalam menjalankan organisasinya dan memanfaatkan lingkungan dengan memilih pengorganisasian sumber daya internal yang tepat. Hal ini sejalan dengan pendapat Musbikin (2013) yang menyatakan bahwa kepemimpinan kepala sekolah yang baik akan menjadi penentu bagi peningkatan mutu pendidikan.

\section{Kewirausahaan}

Penanaman nilai-nilai cinta lingkungan kepada masyarakat sekolah terutama anakanak dari kebiasaan menjadi pembiasaan, dan mempadukan praktek peduli lingkungan dari muatan pelajaran pendidikan lingkungan hidup yang kita pelajari disekolah. Banyak inovasi yang diciptakan sekolah salah satunya menciptakan minuman dari pengelolaan lingkungan tadi. Ada minuman dari tanaman yang marak di tahun 2007 yaitu rosella yang kita olah menjadi minuman. Inovasi untuk pengembangan sekolah dari merawat pohon, pengelolaan sampah, pengembangan sarana dan prasarana sekolah, sampai kepada pembiasaan siswa dalam menjaga lingkungan sekolah untuk mewujudkan program adiwiyata adalah Penghijauan lingkungan sekolah. inovasi-inovasi yang diciptakan tidak terlepas dari program adiwiyata yang mendukung ketercapaian pendidikan lingkungan hidup yang membiasakan masyarakat sekolah untuk peduli terhadap lingkungan.

Dimensi kewirausahaan tentang motivasi dan fungsi pokok, kepala sekolah selalu mengadakan lomba-lomba yang bertemakan peduli lingkungan dan memberi reward bagi anak-anak dan kelompok-kelompok yang memenangkan setiap perlombaan yang kita buat. Para pemenang perlombaan itu kita didik kembali untuk digunakan sebagai perwakilan sekolah dalam perlombaan bertemakan lingkungan baik dari tingkat kecamatan, sampai kepada tingkat provinsi. Inilah bentuk motivasi yang diberikan supaya siswa selaku masyarakat sekolah mampu berpartisipasi aktif dalam mewujudkan program adiwiyata sekolah.

Dimensi kewirausahaan kepala sekolah merupakan pimpinan tunggal yang disekolah yang mempunyai tanggung jawab tunggal dalam mencapai tujuan sekolah. Mulyasa (2012) berpendapat bahwa kepala sekolah merupakan pimpinan tunggal di sekolah yang mempunyai tanggung jawab untuk mengajar dan mempengaruhi semua pihak yang terlibat dalam kegiatan pendidikan di sekolah untuk bekerjasama dalam mencapai tujuan sekolah. Menurut Wahjosumidjo (2011), -kepala sekolah dapat didefenisikan sebagai seorang tenaga fungsional guru yang diberi tugas untuk memimpin suatu sekolah dimana 
diselenggarakan proses belajar mengajar. Kepala sekolah adalah guru yang diberikan tugas tambahan untuk memimpin sekolah. Dapat disimpulkan bahwa kepala sekolah adalah seorang pemimpin disekolah yang memiliki tanggung jawab dalam memberdayakan semua sumber daya yang ada disekolah untuk mencapai tujuan sekolah.

\section{Supervisi}

Supervisi akademik dilakukan untuk memuat nilai-nilai lingkungan hidup kedalam muatan pelajaran dan selalu dievaluasi keberhasilannya untuk kelanjutan pembelajaran yang berwawasan lingkungan.

Dimensi supervisi tentang tindak lanjut supervisi akademik yakni memperbaiki kendala-kendala pembelajaran yang berkaitan dengan lingkungan hidup baik itu teorinya sampai kepada prakteknya. Penanaman nilai-nilai cinta lingkungan untuk menjadi ruh dalam diri siswa yang akan menjadi agen-agen perubahan. Penanaman nilai-nilai cinta lingkungan dilakukan oleh guru berbagai cara demi terwujudnya program adiwiyata sekolah. Kendala-kendala untuk ketercapaian program lingkungan hidup dibicarakan bersama pada rapat sekolah untuk kelanjutan keberlangsungan program adiwiyata sekolah.

Mulyasa (2012) berpendapat bahwa kepala sekolah merupakan pimpinan tunggal di sekolah yang mempunyai tanggung jawab untuk mengajar dan mempengaruhi semua pihak yang terlibat dalam kegiatan pendidikan di sekolah untuk bekerjasama dalam mencapai tujuan sekolah.

Menurut Wahjosumidjo (2011), kepala sekolah dapat didefenisikan sebagai seorang tenaga fungsional guru yang diberi tugas untuk memimpin suatu sekolah di mana diselenggarakan proses belajar mengajar. Kepala sekolah adalah guru yang diberikan tugas tambahan untuk memimpin sekolah. Dapat disimpulkan bahwa kepala sekolah adalah seorang pemimpin di sekolah yang memiliki tanggung jawab dalam memberdayakan semua sumber daya yang ada di sekolah untuk mencapai tujuan sekolah.

\section{Sosial}

Kerja sama sekolah dalam mewujudkan program adiwiyata yaitu adanya gotong royong sekolah yang melibatkan siswa dan wali murid. MOU dengan pihak terkait dibuat untuk dukungan dan sumbangsih tenaga dalam pencapaian program adiwiyata. Kerjasama dibangun sekolah dengan melibatkan langsung pihak-pihak terkait untuk keefektifan dalam pencapapaian program adiwiyata sehingga mampu menambah daya dukung sekolah dalam program yang dijalankannya.

Pengaruh kepemimpinan kepala sekolah sangat besar dalam mewujudkan program adiwiyata. Karena kepemimpinan harus memberi tauladan yang baik untuk mendukung program yang direncanakannya. Pemimpin harus berpartisipasi aktif didalam dan diluar lingkungan sekolah dengan merangkul seluruh pihak terkait untuk ketercapaian program yang telah direncanakan. Keterbukaan berkomunikasi yang baik sangatlah penting supaya menjadi 1 visi dan misi demi tercapainya sekolah adiwiyata. Dari situ kepemimpinan akan dipertanggungjawabkan dalam pelaporan yang dibuat untuk dieksekusi kebenaran dari program yang dijalankan bersama masyarakat sekolahnya melalui pihak terkait seperti dinas lingkungan hidup dan kementrian lingkungan hidup.

Kompetensi yang dimiliki kepala sekolah sebagai pemimpin harus memiliki mampu berinterkasi social dan mempengaruhi lingkungan sekitarnya. Ini dilakukan 
supaya mereka mampu bertindak dan berpikir sesuai dengan arahan tertentu supaya tujuan dapat tercapai dengan mudah. Hal senada juga disampaikan oleh Haiman (2016) bahwa kepemimpinan adalah suatu proses dimana seseorang memimpin, dan membimbing, yang direfleksikan dengan jiwa seni. Seni yang dimaksud adalah indah dalam mempengaruhi, membimbing dan mengarahkan.

\section{KESIMPULAN}

Langkah ataupun strategi yang dimainkan oleh sebuah lembaga pendidikan merupakan wilayah kerja seorang kepala sekolah selaku pimpinan di sekolah tersebut. Kepala sekolah sebagai sosok ataupun figur yang menjadi motor penggerak kemajuan lembaga pendidikan tentu memiliki strategi agar sekolah yang dipimpinya menjadi sekolah yang bermutu. Untuk itu, kepala sekolah bertugas melaksanakan fungsi-fungsi kepemimpinan, baik yang berhubungan dengan pencapaian tujuan pendidikan maupun penciptaan iklim sekolah yang kondusif bagi terlaksananya proses pendidikan secara efektif dan efisien.

Kepemimpinan kepala sekolah juga berperan sebagai motor penggerak bagi sumber daya sekolah terutama para guru dan karyawan sekolah, sukses tidaknya kegiatan sekolah sebagian besar ditentukan oleh kualitas kepemimpinan yang dimiliki oleh kepala sekolah. Semangat kerja guru dan bawahan lainnya, banyak tergantung pada kepemimpinan kepala sekolah. Para guru/ pegawai akan bekerja dengan baik dan para siswa akan bisa belajar dengan tenang, apabila kepala sekolah mampu mempengaruhi, mengarahkan, mendorong, dan menggerakkan mereka ke arah pencapaian tujuan sekolah secara efektif. Disinilah ketauladanan, keterbukaan, komunikasi, dan pertanggung jawaban kepala sekolah yang dapat membawa sekolah yang dipimpinnya menjadi lebih baik dan terarah sesuai dengan cita-cita yang tertuang dalam visi misi sekolah bersama masyarakat sekolahnya.

Keterbukaan berkomunikasi yang baik sangatlah penting supaya menjadi satu visi dan misi demi tercapainya sekolah adiwiyata. Komunikasi kepala sekolah selaku pimpinan terjaga erat baik pada bagian internal sekolah, sampai kepada bagian eksternal sekolah sehingga beliau mampu menjembatani sekolah untuk mewujudkan program adiwiyata sekolah. Tanggung jawabnya dibuktikan dalam susunan pelaporan yang dibuat bersama para majelis guru untuk dipertanggungjawabkan oleh pihak terkait seperti dinas lingkungan hidup sampai kepada kementrian lingkungan hidup yang dibuktikan dengan diterimanya penghargaan langsung dari bapak presiden Susilo Bambang Yudhoyono.

Pengontrolan Kepala Sekolah dalam Mewujudkan Sekolah Adiwiyata di SD Negeri 18 Pekanbaru. dapat dilakukan oleh beberapa pihak terkait, seperti dari unsur dinas pendidikan dan lingkungan hidup Kota Pekanbaru, Kepala Sekolah, Komite Sekolah, para guru dan para siswa. Termasuk juga pada pengontrolan langsung mengenai program khusus. 
AKSARA: Jurnal Ilmu Pendidikan Nonformal

P-ISSN 2407-8018 E-ISSN 2721-7310 DOI prefix 10.37905

Volume 08, (1), January 2022

http://ejurnal.pps.ung.ac.id/index.php/Aksara

\section{DAFTAR PUSTAKA}

Aji, Y. P. (2018). Kepemimpinan kepala sekolah guna menunjang implementasi program sekolah adiwiyata melalui pengelolaan sampah. Universitas Muhammadiyah Surakarta.

Arikunto, S. (2010). Prosedur penelitian suatu pendekatan praktik. Rineka Cipta.

Assauri, S. (2013). Strategic management: Sustainable competitive advantages. PT RajaGrafindo Persada.

Azrai, E. P., Sigit, D. V., \& Puji, M. (2017). The correlation between environmental awareness and student's participation in go green school activity at adiwiyata's school. Biosfer: Jurnal Pendidikan Biologi, 10(2), 7-11., https://doi.org/10.21009/biosferjpb.10-2.

Basri, B. (2018). Manajemen Kepala Sekolah Dalam Mewujudkan Sekolah Adiwiyata (Studi kasus di SD Negeri 02 Tanah Pak Lambik Kota Padang Panjang). Al-Fikrah: Jurnal Manajemen Pendidikan, 5(1), 101. https://doi.org/10.31958/jaf.v5i1.818.

Benninghaus, Cristian. J, Kremer. K, and Sprenger. S. (2017). "Assessing high-school Students' conceptions of global water consumption and sustainability." International Research in Geographical and Environmental Education, July, 1-17. https://doi.org/10.1080/10382046.2017.1349373.

Caddafie, S. U., Martuti, N. K. T., \& Rudyatmi, C. (2017). The impact of Adiwiyata program on environmental caring character. Journal of Biology Education, 6 (3), 350-356. https://journal.unnes.ac.id/sju/index.php/ujbe/article/view/21090.

Dadang, \& Heni, P. (2018). Jurnal Manajemen \& Bisnis Indonesia. Manajemen bisnis, $8(1), 16-23$.

Guru, P. K., Penguatan, E., Karakter, P., Pembiasaan, S., Bagi, K., Didik, P., Khusus, B., Fauziah, S. B., Mahmudah, F. N., Susatya, E., Asih, W. M., Kamil, I., \& Indrapriyatna, A. S. (2020). Jurnal Manajemen, Kepemimpinan, dan Supervisi Pendidikan., P-ISSN: 2548-7094 E-ISSN 2614-8021. 5(1).

Haris, E., Abas. H.M., \& Wardiana. Y. (2018). Sekolah Adiwiyata: panduan implementasi Adiwiyata Mandiri di sekolah. 1st ed. Erlangga.

Ishak, H. (2019). Manajemen kepala madrasah dalam menanamkan nilai-nilai Adiwiyata di MI Muhammadiyah Ceporan Ngadiluwih Matesih Karanganyar tahun ajaran 2018/2019, Institut Agama Islam Negeri Surakarta.

KLHKRI. (2012). Panduan program Adiwiyata (Wujudkan sekolah peduli dan implementasi kebijakan Adiwiyata dalam upaya lingkungan hidup).

Kurniatun. C.T, \& Suryana. (2016). Kepemimpinan dan manajemen pendidikan dasar, Universitas terbuka.

Loganayaki, B. (2014). Creating environmental awareness for tribal school children. International Journal of Scientific Research. 2 (3), 174176.

AKSARA: Jurnal Ilmu Pendidikan Nonformal 
https://www.worldwidejournals.com/international-journal-of-scientificresearch(IJSR)/recent_issues_pdf/2014/February/February_2014_1391506833_0c3 36 56.pdf.

Maryono. (2015). The implementation of the environmental education at "adiwiyata" schools in pacitan regency (an analysis of the implementation of grindle model policy). Journal of Education and Practice, 6(17), 31-42. https://pdfs.semanticscholar.org/3ba9/10bcf6b9003e57421844dcb98bb842a6a2e0. pdf.

Mendiknas. (2016). Peraturan Menteri Pendidikan Nasional Republik Indonesia, Nomor 23 Tahun 2016 Tentang Standar Penilaian Pendidikan.

Moleong, L. J. (2014). Metode penelitian kualitatif, Edisi Revisi. PT Remaja Rosdakarya.

Mulyasa. (2012). Manajemen \& kepemimpinan kepala sekolah. PT Bumi Aksara.

Musbikin, I. (2013). Menjadi Kepala Sekolah yang Hebat!. Zanava Publishing.

Nurhidayah, R. (2019). Peran kepala madrasah dalam meningkatkan kompetensi profesional guru dalam pelaksanaan progam adiwiyata di madrasah tsanawiyah negeri 2 surakarta tahun pelajaran 2018/2019, Institut Agama Islam Negeri Surakarta.

Pimara, F. (2017). Peran kepala sekolah sebagai pemimpin sekolah dalam meningkatkan mutu sekolah berbasis Adiwiyata di SMA Negeri 1 Tanjunganom Nganjuk. Kajian Moral Dan Kewarganegaraan., 5(01)., 334-348.

Ridwan, (2017). Penerapan Kompetensi Manajerial Kepala Sekolah dalam Pelaksanaan Program Sekolah Adiwiyata di SMA Negeri 1 Pangkalan Bun. Institut Agama Islam Negeri Palangka raya.

Sitisyarah, K., \& Mustika, R. (2017). Penerapan program Adiwiyata di SMP Negeri 13 Palembang. JMKSP Jurnal manajemen, kepemimpinan, dan supervisi pendidika), 2(1).

Sugiyono, (2012). Metode penelitian kuantitatif kualitatif dan R\&D. Alfabeta.

Sukmadinata, N.S. (2013). Metode penelitian pendidikan. PT Remaja Rosdakarya.

Tim Adiwiyata tingkat Nasional kerjasama kementerian lingkungan hidup dengan kementerian pendidikan dan kebudayaan. (2011). Panduan Adiwiyata Sekolah Peduli dan Berbudaya lingkungan.

UNESCO Global Education Monitoring Report. (2016). Place: Inclusive and Sustainable Cities. UNESCO Publishing.

Wahjosumidjo. (2011). Kepemimpinan kepala sekolah: tinjauan teoritik dan permasalahannya. PT Raja Grafindo Persada. 
AKSARA: Jurnal Ilmu Pendidikan Nonformal

P-ISSN 2407-8018 E-ISSN 2721-7310 DOI prefix 10.37905

Volume 08, (1), January 2022

http://ejurnal.pps.ung.ac.id/index.php/Aksara

100 AKSARA: Jurnal Ilmu Pendidikan Nonformal 